\title{
MILLENNIAL AND INTERNET: A POSITIVE BEHAVIORAL EFFECT OF PATHOLOGICAL INTERNET USE (PIU)
}

\author{
Pressca Neging* \\ Universiti Teknologi MARA Malaysia \\ Rosidah Musa \\ Universiti Teknologi MARA Malaysia \\ Jati Kasuma \\ Universiti Teknologi MARA Malaysia \\ Maureen Neging \\ Universiti Teknologi MARA Malaysia
}

\begin{abstract}
Drawing upon the media system dependency (MSD) theory, the current study examined how Millennial of Klang Valley pathological Internet use (PIU) motivations affect their behavioral skills in schools. A total of 656 uppersecondary school students studying in Klang Valley areas of Selangor, Malaysia participated in this survey. Structural Equation Modeling was used to test the significance of the hypotheses. The survey results revealed that media (entertainment, Internet activities and pathological gambling) and personality (anxiety and neuroticism) factors had a significant impact on Millennial PIU. The results demonstrated that PIU - namely obsession, neglect and control disorder - has a positive impact on Millennial behavioral skill; Internet maven. Specifically, those seeking to build a virtual friendship through the Internet reported greater offline relationship and online skills. A theoretical framework adapted from MSD specifically for this study generated new knowledge about factors that support a positive approach to PIU among Millennial.
\end{abstract}

Keywords: Pathological Internet Use (PIU); Media System Dependency (MSD) Theory; Media System; Personality System; Internet Maven.

\section{INTRODUCTION}

The form of communication has changed with the adoption of Internet. It serves as a communication and selling medium to people and organizations. Its ubiquitous nature causes one to be highly dependent on this technology that it interferes with one or more major areas of their life functions such as significant relationships, occupation, school, mental health, personal habits or physical health. This dependence disorder related to Internet use has been given different terminologies such as Internet addiction and pathological Internet use (PIU). High technological development and constant access to the Internet makes Millennials technology-savvy.

Millennials students communicate frequently through the Internet that makes todays' retailers, manufacturers, and advertisers have shifted their promotion mix to social networking sites (SNS).

\footnotetext{
* Corresponding Author: Faculty of Business Management, Universiti Teknologi Mara Cawangan Sarawak, Campus Mukah, PO BOX 162, Jln Boulevard Setiaraja Mukah, 96400 Mukah Sarawak, Malaysia. Tel: +60138209985 Email: pressca288@sarawak.uitm.edu.my
} 
Millennials communicate and interact with their peers constantly through other social networks such as MySpace, Facebook, Yahoo Messenger, Instagram, Snapchat and Twitter. This review on millennial youths concluded that the primary trait of the Millennials is that they are digitally literate.

In Malaysia, the number of its Internet subscribers is expected to reach the 25 million mark in the next three years according to The Economic Report 2013/2014 (The Economic Report, 2013). Being the top twenty Internet countries in Asia (Internet World Stats, 2017) as displayed at Table 1, the highest Internet penetration is found in urban areas such as Klang Valley. This is due to the urbanisation of Klang Valley that leads it to be the most industrialized and fastest-growing economic region in the country (Krimi, Yusop, \& Law; 2008).

In 2014, 73\% of Internet users in Malaysia between the ages of 16-24 who fall into the Millennial cohort were active every day (Statista, 2017). Millennial in Malaysia have shown a greater impact in PIU especially in online gaming as 71\% of Malaysian Internet users spend more than 1 hour/day on cyber social activities in comparison to other peers from Asia-pacific region countries (YCharts, 2015). This occurs because games like online cards, dice, and board games or games of personal skills with peers such as sports betting require them to interact with their peers frequently. In other words, the Internet hooks teens so tenaciously with their peers, that consequently it leads them to new addiction patterns.

Table 1: Asia Top Twenty Internet User as At March 2017

\begin{tabular}{cccc}
\hline \hline No. & Asia Countries & Population- 2017 (Estimated) & Internet Users as at 31 $^{\text {st }}$ March 2017 \\
\hline 1 & Afghanistan & $34,169,169$ & $4,005,414$ \\
2 & Armenia & $3,031,670$ & $2,126,716$ \\
3 & Azerbaijan & $9,973,697$ & $7,531,647$ \\
4 & Bangladesh & $164,827,718$ & $67,245,000$ \\
5 & Bhutan & 792,877 & 295,177 \\
6 & Brunei Darussalam & 434,448 & 310,205 \\
7 & Cambodia & $16,076,370$ & $4,100,000$ \\
8 & China & $1,388,232,693$ & $731,434,547$ \\
9 & Georgia & $3,972,532$ & $2,411,370$ \\
10 & Hong Kong & $7,401,941$ & $6,066,357$ \\
11 & India & $1,342,512,706$ & $462,124,989$ \\
12 & Indonesia & $263,510,146$ & $132,700,000$ \\
13 & Japan & $126,045,211$ & $118,453,595$ \\
14 & Kazakhstan & $18,064,470$ & $13,236,444$ \\
15 & Korea, North & $25,405,296$ & 14,000 \\
16 & Korea, South & $50,704,971$ & $45,314,248$ \\
17 & Kyrgystan & $6,124,945$ & $2,076,220$ \\
18 & Laos & $7,037,521$ & $1,400,000$ \\
19 & Macao & 606,384 & 460,752 \\
20 & Malaysia & $31,164,177$ & $21,684,777$ \\
\hline \hline
\end{tabular}

\section{LITERATURE REVIEW}

\subsection{Determining Factors of Pathological Internet Use (PIU)}

Hughes (1994) suggested three approaches to technological changes. He asserted that the changes are determined by social and cultural constructions, the society shapes and is shaped by technological construction, and technology determines social and cultural changes. All these approaches illustrate that social and cultural construct can determine technological use or vice versa, it may work in reversal 
influence. The founder of PIU, Young (1996) identified that Internet dependents spent nearly eight times the number of hours per week spent by non-dependents using the Internet. This supports her findings on long hours of being online will lead to high Internet dependence among users. Long hours of time online are considered as Internet overuse or excessive Internet use which is described as "other behavioural addiction" and "Impulse Control Disorder" (Tonioni et al., 2012).

However, in a different study by Young (1998a), she concluded that time online is not the only determinant of PIU and calibrating the digital divide using computer ownership and time online indicators may be misleading, as people of different personality traits and preferences use the internet in varied ways (Dawood, Mitsu \& Monica, 2015) PIU may be contributed by online networking and well-being (Sabatini \& Sarracino, 2014), compulsive gambling (Tozzi, Akre, Fleury-Schubert \& Suris, 2013), depression (Ko, et al., 2012), self-esteem (Fioravanti, Dèttore, \& Casale, 2012), parents roles (Salgado et al., 2014), and users' personality (Tan \& Yang, 2014). The power of media system is derived from the dependence of others such as systems, organizations, groups and individuals upon the scarce information resources controlled by the media (DeFleur \& Ball-Rokeach, 1989). Internet is an online media that offers multiple online activities, online applications and social networking sites. Young (1998a) stated that online activities and applications are one of the predictors to PIU. In support of Young's findings, Kuss et al. (2013) mentioned that the use of Twitter and SNS such as Facebook significantly predicted PIU. Among many factors connected with Internet addiction, personality has been shown to profoundly influence Internet use (Weibel, Wissmath, \& Groner, 2010). Out of hundreds personality traits that have been studied, Andreassen et al. (2013) asserted that neuroticism is the main factor for the formation of psychopathology. Serin (2013) also added that neuroticism is the best predictor for PIU, followed by extraversion, psychoticism, and lying. All these findings support that neuroticism predicts PIU (Samarein et al., 2013).

\subsection{Behavioural Effects of Pathological Internet Use (PIU)}

Compulsive Internet use is related with the neglect of other aspects in life. For example, it will impair educational and work performance, affect quality of life and narrow one's range of interests (De Leo \& Wulfert, 2013 and Kabasakal, 2015). Hundreds of studies have emphasized on the negative outcomes of PIU that make it impossible to see the positive side of this technological innovation. It raises doubt as to whether healthy Internet use really exists. The answer is it does. Spada (2014) suggested that heavy Internet use does not affect young people in a negative way. It provides users with the opportunity to connect with people, well beyond time and space constraints. Leung and Lee (2012), found that teens who can locate, browse, and access different information resources and who are knowledgeable about the context under which information were created, perform better both in overall grades and in academic competence. When kids spend many hours online, they are considered as heavy media consumers, and this can cause them to become market maven (Belch, Krentler, \& Willis-Flurry, 2005) and when they are on Internet, they become Internet maven (Barnes \& Pressey, 2016). Internet mavens play an important role in the diffusion of information among their peers and other customers through sharing their personal experiences and providing general information that they have on a product (Kiani, Laroche \& Paulin, 2016). Thus, this maven is claimed as heavy media consumers who are believed to have been sharing their expertise on certain products not only offline but also in the virtual world.

\subsection{Media System Dependency (MSD) Theory}

Several theories can be used to explain Internet motives and effects. However, with notable exceptions, the works of Balakrishnan and Shamim (2013), Zamani-Miandashti et al., (2013), Young (1999) and many other researchers have applied the "uses and gratifications" approach, "attachment theory", 
"theory of planned behaviour" and "social learning theory" to study the effects of Internet. These approaches have often been viewed as limited for a number of reasons. For example, the specific uses and gratifications that have been identified often vary from study to study, which highlights the theoretical nature of the uses and gratifications research. On the other hand, surveys are limited in their ability to identify internal gratifications. Thus, Balakrishnan \& Shamim, (2013), noted that a study on Internet frequently employs uses and gratifications theory when mass media researchers should use other theories to uncover more addictive behaviours among online media users.

Media system dependency (MSD) theory was developed by Sandra Ball-Rokeach and Melvin DeFleur in 1976, with the central tenet that individual's media use is determined by the interrelations among society, media, and audience. Media System Dependency (MSD) theory is adopted because it explains people's dependency level on a media system, which can be compulsive, such that it can lead them to be addicted to it, even though being online does not ensure they would get satisfaction or they would get any good results from it. MSD theory is more attractive than any other theory for explaining the micro-relationship between individuals and media for a variety of reasons. It is a theoretical approach to study how people interact with media. This is supported by Riffe, Lacy, \& Varouhakis, (2008) who affirm that the theory covers a much wider range of behaviours towards media and makes it the most suitable theory to examine behavioural effects among Internet dependents.

\section{RESEARCH MODEL AND HYPOTHESIS}

The MSD research model developed specifically for this study from the general MSD framework is depicted in Figure 1. It was designed to examine whether media system (Internet activities) and personality system (neuroticism) can enhance Millennial PIU, and whether their PIU have a direct impact on their Internet maven behavioural skill. Three hypotheses were proposed to test and justify the model.

Figure 1: MSD Model

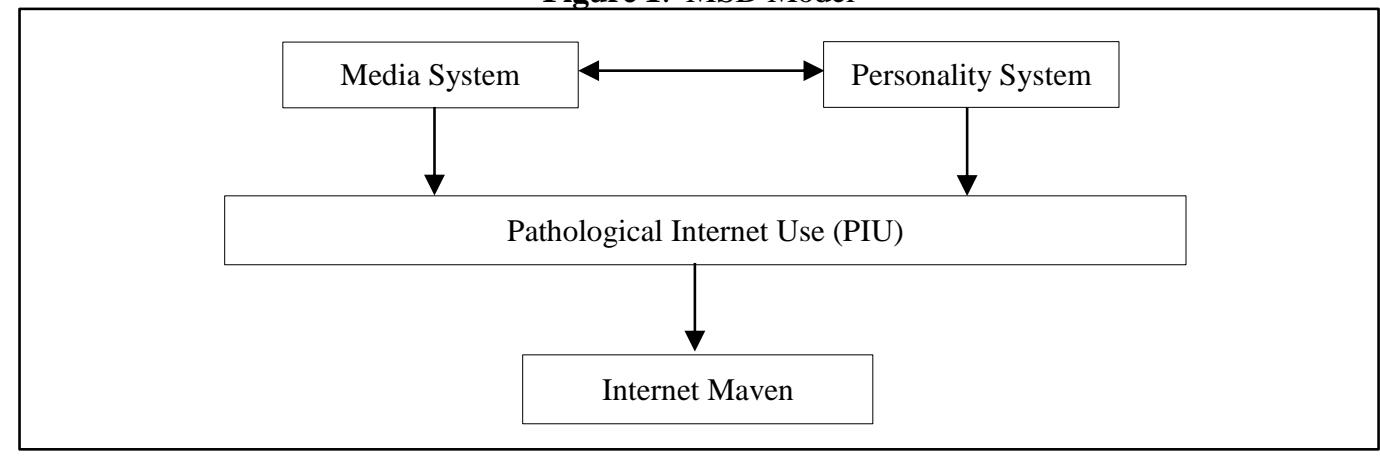

\subsection{Media System}

Millennial consumers are very connected socially and share product information frequently over Internet. They visited social media on a daily basis and social networking sites have become a crucial part of their lives (Pate \& Adams, 2013). Hence, media usage creates growth, develops and helps the Millennial students to enhance their social skills and abilities in order to achieve social success (Zorofi, 2013). This is supported by Magsamen-Conrad \& Billotte-Verhoff (2014), who suggested that PIU 
positively affect users well-being provided the Internet content is also positive and develops social interaction, builds relationships, or promotes a sense of community. Based on this fact, the first hypothesis is formulated as follows.

H1: Media system has a positive effect on PIU among Klang Valley Millennial.

\subsection{Personality System}

Because of its wide activities and applications, Internet overuse disorder tends to vary greatly. This has been said to be a possible function of personality (Burnay et al., 2015). However, all these psychological traits and co-morbidities associated with compulsive use of Internet show variance across individuals who exhibit PIU (Burnay et al., 2015), Therefore, the second hypothesis is proposed as follows.

H2: Personality system has a positive effect on PIU among Klang Valley Millennial.

\subsection{Internet Maven}

Barnes \& Pressey, (2016) described market mavens as agents who are 'super consumers' and enthusiastic disseminators of generalized marketplace information. These agents are considered as digital natives, the Millennial. As Internet technologies have evolved over the past decade, market mavenism is transferable from real-life settings to the Internet (i.e. virtual worlds). Due to this, the presence of Internet maven is found in virtual worlds and they are actively involved in online communication and trialing new products and services. This leads to the formulation of the last hypothesis as follows.

H3: PIU has a positive influence on development of Internet maven characteristics among Klang Valley Millennial.

\section{METHODOLOGY}

A survey questionnaire of this study was developed from published studies and previous surveys as a measurement tool to test predicting and impact factors to PIU among Millennial. The survey's three key constructs were 'media system, 'personality system', 'PIU' and 'Internet maven'. Media system questions were developed on the basis of Millennial use of the Internet by Hwang (2007) work on Depressive Mood Self-Detection Scale (ADMSS) and Klang Valley Millennial Internet activities.

Questions on Internet use:

$>$ Easy to relieve tension - Ent 19

$>$ Relax and find joy - Ent 18

Questions on Internet activities:

$>$ Do downloading - Int27

$>$ Do online gaming - Int28

Personality system were based on the work of Eysenck \& Eysenck's (1975) Personality System Scale on Neuroticism:

$>$ I suffer from nerves - Anx1

$>$ I call myself a nervous person - Anx2 
$>$ I worry too long after an embarrassing experience - Anx3

$>$ I am a worrier - Anx4

$>$ I call myself tense or 'highly strung' - Anx5

$>$ My feelings get hurt easily - Neu25

$>$ I often feel "fed up" - Neu26

Pathological Internet use questions were based on Problematic Internet Use Questionnaires (PIUQ) by Demetrovics, Szeredi \& Rózsa, (2008).

Questions on PIU:

$>$ How often do you feel tense, irritated, or stressed if you cannot use the Internet for as long as you want to Obs32

$>$ How often do you feel stressed if you cannot use the Internet for a few days - Obs33

$>$ How often does it happen to you that you feel depressed, moody, or nervous when you are not on the Internet and these feelings stop once you are back online - Obs 34

$>$ How often does it happen to you that you wish to decrease the amount of time spent online but you do not succeed - Ctr35

$>$ How often do you feel that you should decrease the amount of time spent online - Ctr36

$>$ How often do you feel that your Internet usage causes problems for you - Ctr37

$>$ How often do you realize saying when you are online, "just a couple of more minutes and I will stop" - Ctr38

$>$ How often do you try to conceal the amount of time spent online - Ctr39

$>$ How often do you think that you should ask for help in relation to your Internet use - Ctr40

$>$ How often do you choose the Internet rather than being with your family - Neg41

$>$ How often do you neglect household chores to spend more time online - Neg42

$>$ How often does the use of Internet impair your work or your efficacy - Neg43

$>$ How often do you spend time online when you'd rather sleep- Neg44

$>$ How often do you choose the Internet rather than going out with somebody to have some fun - Neg45

$>$ How often do people in your life complain about spending too much time online - Neg46

Internet maven questions were constructed based on the work of Feick \& Price's (1987) on market maven scale.

Questions on Internet maven:

$>$ People often ask me for information to get the best buy on several types of products, places to shop, or sales Mav47

$>$ My friends think of me as a good source of information for new products or sales - Mav48

$>$ If someone asked me where to get the best buy on several types of products, I could tell the person where to shop - Mav49

I like to help people by providing them with information about many kinds of products - Mav50

$>$ I like to introduce new brands to my friends - Mav51

$>$ Think about a person who has information about a variety of products and likes to share this information with others. This person knows about new products, sales, stores, and so on, but does not necessarily feel that he or she is an expert on any one particular product. How strongly would you agree that this description fits you Mav52

\subsection{Data Collection}

Six hundred and fifty six (656) respondents (316 males and 340 females) undertook the refined survey to test the hypotheses models developed for this study. The respondents were at the age group of 16 to 
17 from ten (10) randomly selected schools from five (5) selected regions (Kuala Lumpur, Petaling, Klang, Gombak, Hulu Langat) in Klang Valley. All of these respondents were studying in Klang Valley urban schools and were also selected based on Ministry of Higher Education (MOHE) in Malaysia approval. The schools' principals and teachers cooperated and supported the study. They allocated a specific session for students to participate at the actual survey. The researchers initially gave the students a short talk on Internet opportunities and challenges, then administered the survey forms, provided the required instructions and guided the students throughout the whole actual data collection sessions with the help of research assistants. Any students who never used Internet were excluded from the study.

\subsection{Data Analysis}

\subsubsection{Assessment of the Measurement Tools}

In this study, the survey's four key constructs' psychometric properties were assessed by examining their reliability, convergent validity and discriminant validity. Babbie (2001) defined reliability as the extent to which the technique will produce the same results when it is applied on repeated trials. Reliability, or internal consistency, in this study is assessed using Cronbach's alpha to test the internal consistency of the survey's key constructs. As shown in Table 1, the reliability measures ranged from 0.77 to 0.90 , equal to or exceeding the 0.70 cut-off values and thus indicating an acceptable level of internal consistency (Nunnally, 1978).

Table 1: Reliability of Constructs

\begin{tabular}{ccc}
\hline \hline Constructs & No. of Items & Cronbach's Alpha \\
\hline Media system & 10 & 0.84 \\
Personality system & 10 & 0.77 \\
Pathological Internet use (PIU) & 12 & 0.90 \\
Internet maven & 6 & 0.87 \\
\hline \hline
\end{tabular}

Convergent validity was assessed and the result is shown on Table 2, standardized factor loadings are above 0.50 , which indicates an adequate level of convergent validity. Items Int 27 and Int 28 were retained because according to Chang et al. (2014), greater engagement in online activities (i.e., social network website use, online gaming) predicted the initiation of PIU.

Convergent validity was also tested by computing the Average Variance Extracted (AVE), which is 'the amount of variance that a latent variable component captures from its indicators in relation to the amount due to measurement error' (Crossler 2010, p. 7). The AVE was equal or larger than the recommended threshold of .50 (Bagozzi and Yi, 1988), as shown in Table 3. Composite reliability (CR) was calculated to confirm the scale's reliability. The CR of all constructs was also above 0.6 (see Table 3), thus indicating adequate convergent validity of the items in each construct (Bagozzi \& Yi, 1988).

Discriminant validity can be assessed by comparing the correlation of each construct with the square root of the Average Variance Extracted (AVE) (Fornell \& Larcker 1981). As illustrated in Table 3, the square root of the AVE (diagonal elements in Table 3) of each construct is equal or larger than the recommended threshold of .50 (Bagozzi and Yi, 1988). Therefore, this satisfies the discriminant validity of the constructs. Since all the items had adequate reliability and validity, all the measurement items were used for testing the research model. 
Table 2: Measurement Model Evaluation

\begin{tabular}{|c|c|c|c|c|c|c|}
\hline Constructs & Items & $\begin{array}{c}\text { Standardized } \\
\text { loading }\end{array}$ & $\begin{array}{c}\text { Cronbach's } \\
\text { alpha }(\alpha)\end{array}$ & $\begin{array}{c}\text { Composite } \\
\text { reliability (CR) }\end{array}$ & $\begin{array}{l}\text { Average variance } \\
\text { extracted (AVE) }\end{array}$ & $\begin{array}{c}\text { Squared multiple } \\
\text { correlations }\end{array}$ \\
\hline \multirow[t]{5}{*}{ Media System } & Ent18 & 0.85 & & & & \\
\hline & Ent19 & 0.78 & & & & \\
\hline & Int27 & 0.58 & & & & \\
\hline & Int28 & 0.58 & & & & \\
\hline & & & 0.75 & 0.80 & 0.50 & 0.42 \\
\hline \multirow{9}{*}{$\begin{array}{l}\text { Personality } \\
\text { System }\end{array}$} & Anx1 & 0.69 & & & & \\
\hline & Anx2 & 0.71 & & & & \\
\hline & Anx3 & 0.71 & & & & \\
\hline & Anx4 & 0.72 & & & & \\
\hline & Anx5 & 0.72 & & & & \\
\hline & Anx6 & 0.68 & & & & \\
\hline & Neu25 & 0.68 & & & & \\
\hline & Neu26 & 0.75 & & & & \\
\hline & & & 0.88 & 0.89 & 0.50 & 0.47 \\
\hline \multirow[t]{12}{*}{ PIU } & Obs32 & 0.73 & & & & \\
\hline & Obs33 & 0.72 & & & & \\
\hline & Obs34 & 0.75 & & & & \\
\hline & Ctr35 & 0.77 & & & & \\
\hline & $\mathrm{Ctr} 37$ & 0.70 & & & & \\
\hline & $\mathrm{Ctr} 38$ & 0.62 & & & & \\
\hline & Ctr39 & 0.64 & & & & \\
\hline & Neg41 & 0.68 & & & & \\
\hline & Neg42 & 0.77 & & & & \\
\hline & Neg43 & 0.62 & & & & \\
\hline & Neg44 & 0.72 & & & & \\
\hline & & & 0.86 & 0.92 & 0.50 & 0.55 \\
\hline Internet & Mav48 & 0.86 & & & & \\
\hline \multirow[t]{4}{*}{ Maven } & Mav49 & 0.84 & & & & \\
\hline & Mav50 & 0.67 & & & & \\
\hline & Mav52 & 0.61 & & & & \\
\hline & & & 0.88 & 0.88 & 0.65 & 0.36 \\
\hline
\end{tabular}

Table 3: Correlation of Latent Construct, AVE, R-Square and Composite Reliability

\begin{tabular}{ccccc}
\hline \hline Constructs & Media System & Personality System & PIU & Internet Maven \\
\hline Media System & $\mathbf{0 . 5 0}$ & & & \\
Personality System & $0.188^{* *}$ & $\mathbf{0 . 5 0}$ & & \\
PIU & $0.351^{* *}$ & $0.418^{* *}$ & $\mathbf{0 . 5 0}$ & \\
Internet Maven & $0.263^{* *}$ & $0.124^{* *}$ & $0.279^{* *}$ & $\mathbf{0 . 6 5}$ \\
\hline R-Squared Correlations & 0.42 & 0.47 & 0.55 & 0.36 \\
Composite Reliability & 0.80 & 0.89 & 0.92 & 0.88 \\
\hline \hline
\end{tabular}

\subsubsection{Assessment of the Research Model}

This study used the Statistical Package for Social Sciences (SPSS) version 22 and AMOS Version 22 to analyse the preliminary and main survey data. AMOS was used to test the hypotheses using Structural Equation Modeling (SEM). After measurement model assessment, the structural model was evaluated with goodness-of-fit indices. They were examined to assess if the hypothesized structural model fit the data. The hypothesised structural model had a significant $\chi^{2}$ value $\left(\chi^{2}=2003.338, d f=1027, p=0.000\right)$ thereby indicating an adequate fit of the data to the hypothesised model. 


\section{FINDINGS AND DISCUSSIONS}

Table 4 displays that H1 (media system has a positive effect on PIU among Millennial) with significant results of $\mathrm{P}<0.001$ and a t-value of $6.09, \mathrm{H} 2$ (personality system has a positive effect on PIU among urban Millennial) with significant results of $\mathrm{P}<0.001$ and a t-value of 7.94 and H3 (PIU has a positive influence on development of Internet maven characteristics among Millennial) with returned results of $\mathrm{P}<0.001$ and a t-value of 7.04. The estimation of the hypothesised structural model showed that three of the hypothesised links were significant. This provides evidence to support the theory that media usage and personality system including neurotic trait encourage Millennial to be pathological Internet users and decide the outcome of PIU, Internet maven.

Table 4: Summary of Findings

\begin{tabular}{ccccc}
\hline \hline Hypothesis & Hypotheses path & $\begin{array}{c}\text { Standardised } \\
\text { estimates }\end{array}$ & t-value & $\begin{array}{c}\text { Supported/ } \\
\text { not supported }\end{array}$ \\
\hline H1 & Media system $\rightarrow$ Pathological Internet use & 0.30 & 6.07 & Yes \\
H2 & Personality system $\rightarrow$ Pathological Internet use & 0.40 & 7.94 & Yes \\
H3 & Pathological Internet use $\rightarrow$ Internet maven & 0.36 & 7.04 & Yes \\
\hline \hline
\end{tabular}

The results of this study have validated the investigative research model, based on Ball-Rokeach and DeFleur (1976), MSD Theory, which was developed to explore the relationship between PIU among Klang Valley Millennial factors and its effect. The model is able to explain that media system such as Internet use and activities (H1) and personality system of neurotic users (H2) have significant, positive impacts on PIU among Klang Valley Millennial. This reinforces the point that caretakers must be vigilant in monitoring Millennial Internet use because the higher degree of online activities, especially of pathological gaming predicted a substantial increase in the frequency and the duration of gaming sessions, 6 months thereafter (Lemmens, Valkenburg, \& Peter, 2011); and hence, will lead to PIU. Meanwhile, regarding personality factor, namely neuroticism significantly and highly predicted PIU. Neuroticism increases with PIU, indicating that those Millennial constantly worry and experience anxiety. However, Millennial in this study did not develop negative emotions like other pathological Internet users from many previous international studies because they are not exposed to violence and aggression. This finding disagrees with that of Kuss et al., (2014) who linked neuroticism to violence and aggression.

This is proven by the result of the third hypothesis $(\mathrm{H} 3)$ on Internet maven and it states that PIU contributes to a positive behavioural skill rather than behavioural disorder or addiction, namely Internet maven among Klang Valley Millennial. This provides evidence that Internet maven is a person who knows about new products, sales, stores, and so on, but does not necessarily feel that he or she is an expert on any one particular product. The effect of PIU on Internet maven scored the highest value and it is consistent with the characteristics of the market maven as suggested by Feick and Price (1987). The idea is supported by Belch et al. (2005) who claimed that teen Internet mavens considered themselves and other family members as highly involved with the Internet. This is because media usage creates growth, develops, and helps the students to enhance their social skills and abilities to achieve social success (Zorofi, 2013).

Thus, the major finding from this study that PIU affects Internet maven plays key roles in understanding the opportunities of heavy Internet use among Millennial. This pattern demonstrates the need for a balanced approach to nurturing millennial positive online behaviour, based on a sound knowledge of MSD Theory. Future research may need to focus on participants from other cities or states with different age groups and generation cohorts. However, if the purpose is to obtain further insights about this generation, it would be best to adopt smartphone as its media system and assess the effects of the 
excessive use of the smartphone. This is because from current investigations, the smartphone is the frequently used gadget to access Facebook, Twitter and surf Tumbler, compared with netbook and laptop. Additionally, perceived enjoyment, satisfaction, personal innovativeness, and loneliness do not affect compulsive usage of Internet (Park \& Lee, 2011). Thus, the findings would be useful for online retailers, smartphone marketing personnel, and researchers to understand smartphone users.

\section{IMPLICATION AND CONCLUSION}

The theoretical basis, MSD theory for this empirical study facilitates media usage and personality approach to Millennial Internet use, resulting in a positive behavioural outcome. It also demonstrates that media and personality system have direct impacts on PIU among Klang Valley Millennial. The use of MSD Theory to understand aspects of millennial online behavior marks an important addition to this theory that is widely adopted to examine traditional media users in the past. The proposed MSD Theory from the general MSD Theory framework can be adapted for research into examining behavioral issues among pathological smartphone users.

By employing the MSD Theory, this study was able to grasp the importance of the media system in terms of its applications and functionality and that it is the online media that determines PIU. The results of this empirical research are important to the industry practitioners in revealing that these Internet mavens and Internet literate users are considered as influential in the purchase decision. Interestingly, the results affirmed the millennial traits and that the tech savvy generation can evaluate the strengths and weaknesses, control the capabilities and limits of information technologies being given to them.

This study has brought to light a number of imperative knowledge to improve the understanding of PIU determinants and outcomes. The results prove that media system and personality system such as neurotic Millennial directly influence PIU. Millennial heavy Internet usage is not a serious addiction that could cause them to suffer loneliness and depression, as suffered by those in other developed countries. This is because they exercise self-control in their Internet usage which in turn developed them to be a better Internet mavens.

\section{ACKNOWLEDGMENT}

The authors would like to thank the Ministry of Higher Education, Malaysia (MOHE) for providing the grant under the Fundamental Research Grant Scheme (FRGS) and Universiti Teknologi MARA for the support in facilitating this research.

\section{REFERENCES}

Andreassen, C. S., Griffiths, M. D., Gjertsen, S. R., Krossbakken, E., Kvan, S., \& Ståle Pallesen, S. (2013). The relationships between behavioral addictions and the five-factor model of personality. Journal of Behavioral Addictions, 2(2), 90-99.

Babbie, E. (2001). Qualitative field research: The basics of social research. USA: Cengage Learning.

Bagozzi, R. P., \& Yi, Y. (1988). On the evaluation of structural equation models. Journal of the Academy of Marketing Science, 16(1), 74-94.

Balakrishnan, V., \& Shamim, A. (2013). Malaysian facebookers: Motives and addictive behaviours unravelled. Computers in Human Behavior, 29(4), 1342-1349. 
Ball-Rokeach, S. J., \& DeFleur, M. L. (1976). A dependency model of mass media effects. Communication Research, 3(1), 3-21.

Barnes, S. J. \& Pressey, A. D. (2016). Cyber-mavens and online flow experiences: Evidence from virtual worlds. Technological Forecasting \& Social Change, 111, 285-296

Belch, M. A., Krentler, K. A., \& Willis-Flurry, L. A. (2005). Teen internet mavens: Influence in family decision making. Journal of Business Research, 58(5), 569-575.

Burnay, J., Billieux, J., Blairy, S., \& Larøi, F. (2015). Which psychological factors influence Internet addiction? Evidence through an integrative model. Computers in Human Behavior, 43, 28-34.

Chang, F. C., Chiu, C. H., Lee, C. M., Chen, P. H., \& Miao, N. F. (2014). Predictors of the initiation and persistence of Internet addiction among adolescents in Taiwan. Addictive Behaviors, 39(10), 1434-1440.

Crossler, R. E. (2010). Protection motivation theory: Understanding determinants to backing up personal data. Paper presented at 43rd Hawaii International Conference, Honolulu, USA.

Dawood, E., Mitsu, R. \& Monica, A. (2015). Patterns of Internet Use among Saudi Public Adults: A Cross Sectional Study. Journal of Health, Medicine and Nursing, 13, 18-27.

De Leo, J. A., \& Wulfert, E. (2013). Problematic Internet use and other risky behaviors in college adolescents: An application of problem-behavior theory. Psychology Addict Behavior, 27(1), 133-141.

DeFleur, M. L., \& Ball-Rokeach, S. (1989). Theories of mass communication. NY: Longman.

Demetrovics, Z., Szeredi, B., \& Rózsa, S. (2008). The three-factor model of Internet addiction: The development of the Problematic Internet Use Questionnaire. Behavior Research Methods, 40(2), 563-574.

Eysenck, H. J., \& Eysenck, S. B. G. (1975). Manual of the Eysenck Personality Questionnaire. London: Hodder \& Stoughton.

Feick, L. F., \& Price, L. L. (1987). The market maven: A diffuser of market information. Journal of Marketing, 51(1), 83-97.

Fioravanti, G., Dèttore, D., \& Casale, S. (2012). Adolescent Internet addiction: Testing the association between self-esteem, the perception of Internet attributes, and preference for online social interactions. Cyberpsychology, Behavior and Social Networking, 15(6), 318-323.

Fornell, C., \& Larcker, D. F. (1981). Evaluating Structural Equation Models with Unobservable Variables and Measurement Error. Journal of Marketing Research, 18(1), 39-50.

Hughes, T. P. (1994). Technological Momentum. In M. R. Smith \& L. Marx (eds), Does technology drive history? The dilemma of technological determinism (PP. 100-114). Cambridge, MA: MIT Press.

Hwang, J., M. (2007). Being young and feeling blue in Taiwan: an empirical study of the relationship between adolescent depressive mood and online and offline activities (Unpublished doctoral dissertation). State University of New York, United States.

Internet World Stats. (2017). The Asian Internet Statistics. Retrieved July 31, 2017, from Internetworldstats.com/asia/my.htm

Kabasakal, Z. (2015). Life satisfaction and family functions as-predictors of problematic Internet use in university students. Computers in Human Behavior, 53, 294-304.

Kiani, I., Laroche, M. \& Paulin, M. (2016). Development of market Mavenism traits: Antecedents and moderating effects of culture, gender, and personal beliefs. Journal of Business Research, 69(3), 1120-1129.

Ko, C. H., Yen, J. Y., Yen, C. F., Chen, C. S., \& Chen, C. C. (2012). The association between Internet addiction and psychiatric disorder: A review of the literature. European Psychiatry, 27(1), 1-8.

Krimi, M., S., Yusop, Z., \& Law, S., H. (2008). Regional development disparities in Malaysia. Journal of American Science, 6(3), 70-78.

Kuss, D. J., Griffiths, M. D., Karila, L., \& Billieux, J. (2014). Internet addiction: A systematic review of epidemiological research for the last decade. Current Pharmaceutical Design, 20(25), 4026-4052. 
Kuss, D. J., van Rooij, A. J., Shorter, G. W., Griffiths, M. D., \& van de Mheen, D. (2013). Internet addiction in adolescents: Prevalence and risk factors. Computers in Human Behavior, 29(5), 1987-1996.

Lemmens, J. S., Valkenburg, P. M. \& Peter, J. (2011). Psychosocial causes and consequences of pathological gaming. Computers in Human Behavior, 27(1), 144-152

Leung, L., \& Lee, P. S. N. (2012). Impact of internet literacy, internet addition symptoms, and internet activities on academic performance. Social Science Computer Review, 30(4), 403-418.

Magsamen-Conrad, K., Billotte-Verhoff C. \& Greene K. (2014). Technology addiction's contribution to mental wellbeing: The positive effect of online social capital. Computers in Human Behavior, 40, 23-30.

Nunnally, J.C. (1978). Psychometric theory. New York: McGraw-Hill.

Park, B. W., \& Lee, K. C. (2011). The effect of users' characteristics and experiential factors on the compulsive usage of the smartphone. In G. S. Tomar, W. I. Grosky, Tai-hoon Kim, Sabah Mohammed, Sanjoy Kumar Saha (Eds.), Ubiquitous computing and multimedia applications (pp. 438-446), Proccedings of International Conference, UCMA 2010, Miyazaki, Japan, June 23-25, 2010. Berlin Heidelberg: Springer.

Pate, S. S., \& Adams, M. (2013). The Influence of Social Networking Sites on Buying Behaviors of Millennials. Atlantic Marketing Journal, 2(1), 92-109.

Riffe, D., Lacy, S., \& Varouhakis, M. (2008). Media System Dependency Theory and Using the Internet for In-depth, Specialized Information. WJMCR. (Unpublished doctoral dissertation). Ohio University and Michigan State University.

Sabatini, F., \& Sarracino, F. (2014). Online networks and subjective well-being. MPRA Paper No. 56436

Salgado, P. G., Boubeta, A. R., Tobío, T. B., Mallou, J. V., \& Couto, C. B. (2014). Evaluation and early detection of problematic Internet use in adolescents. Psicothema, 26(1), 21-26.

Samarein, Z. A., Far, N. S., Yekleh, M., Tahmasebi, S., Ramezani, Y. V., \& Sandi, L. (2013). Relationship between personality traits and Internet addiction of students at Kharazmi University. International Journal of Psychology and Behavioral Research, 2(1), 10-17.

Serin N. B. (2013). An examination of predictor variables for problematic Internet use. The Turkish Online Journal of Educational Technology, 10(3), 54-62.

Spada, M. M. (2014). An overview of problematic Internet use. Addictive Behaviors, 39(1), 3-6.

Statista. (2017). Number of internet users in Malaysia from 2015 to 2022 (in millions). The Statistics Portal. Retrieved July 2, 2017, from https:/www.statista.com/statistics/553752/number-ofinternet-users-in-malaysia/

Tan, W.-K., \& Yang. C.-Y. (2014). Internet applications use and personality. Telematics and Informatics, 31(1), 27-38.

The Economic Report. (2013). Malaysia Internet Subscribers Keep Growing. Retrieved July 31, 2017, from http://www.internetlivestats.com/internet-users/malaysia/

Tonioni, F., D’Alessandris, L., Lai, C., Martinelli, D., Corvino, S., Vasale, M., Fanella F, Aceto, P., \& Bria, P. (2012). Internet addiction: Hours spent online, behaviors and psychological symptoms. General Hospital Psychiatry, 34(1), 80-87.

Tozzi, L., Akre, C., Fleury-Schubert, A., \& Suris, J. C. (2013). Gambling among youths in Switzerland and its association with other addictive behaviours. Schweizerische Medizinische Wochenschrift, 143, w13768. doi: 10.4414/smw.2013.13768.

Weibel, D., Wissmath, B., \& Groner, R. (2010). Motives for Creating a Private Website and Personality of Personal Homepage Owners in Terms of Extraversion and Heuristic Orientation. Cyberpsychology. Journal of Psychosocial Research on Cyberspace, 4(1). Retrieved from http://cyberpsychology.eu/view.php?cisloclanku=2010053101\&article $=5$

YCharts. (2015). Malaysia Internet Users: 71.06 /100ppl for 2015. Retrieved July 2, 2017, from https://ycharts.com/indicators/malaysia_internet_users_per_100 
Young, K. S. (1996). Internet Addiction: The emergence of a new clinical disorder. Paper presented at the 104th Annual Meeting of the American Psychological Association, Toronto, Ontario, Canada.

Young, K. S. (1998). Internet addiction: The emergence of a new clinical disorder. Cyber Psychology and Behaviour, 1(3), 237-244.

Young, K. S. (1999). Internet addiction: Symptoms, evaluation and treatment. In L. VandeCreek \& T. Jackson (Eds.), Innovations in clinical practice: A source book (pp. 19-31). Sarasota, FL: Professional Resource.

Zamani-Miandashti, N., Memarbashi, P., \& Khalighzadeh, P. (2013). The prediction of Internet utilization behavior of undergraduate agricultural students: An application of the theory of planned behaviour. The International Information \& Library Review, 45(3-4), 114-126.

Zorofi, M. (2013). Relationship between media usage and skills development of students. Research Journal of Applied Sciences, 5(6), 1876-1882. 